\title{
The Knowladge of Police Officers at Pancur Batu Sector about Autopsy
}

\author{
Erwin Sembiring, Surjit Singh, Agustinus Sitepu \\ Department of Forensic and Medicolegal of Faculty of Medicin Universitas Sumatera Utara \\ DOI: 10.29322/IJSRP.11.02.2021.p11043 \\ http://dx.doi.org/10.29322/IJSRP.11.02.2021.p11043
}

\begin{abstract}
Nowadays, autopsy is rarely conducted by forensic doctor with the reason of low demand from investigators. Also, it is as the effect of negative image of the people to the action of autopsy such as human organs trafficking, pity feeling from families of victim, local culture prohibition, or may be also as the lack of knowledge of the police officers of Indonesia regarding autopsy. It is as the hindrance for the investigator to reveal civil action cases of murder and can be as the way for legal practitioners causing unfair for either the victim or a suspect since the real cause of the dead cannot be exactly determined.

High criminal cases as the effect of civil action and dead victims on traffic accidents reported by the investigators via letter of request of Visum Et Revertum in field that in fact at mortuary installation of Adam Malik hospital/Forensic Department and Medikolegal Faculty of Medicine USU, it showed only outside checking without conducting inside (autopsy) and outside checking to assure one case. The writer conducts this research to know the knowledge of police officers at Pancur Batu sector about autopsy.

The method used in this research was survey research with cross sectional descriptive design. The population were all policies at Pancur Batu sector in Traffic and Crime unit. Sample taking technique used Total Sampling. The instrument used was questionnaire. The obtained data was analyzed using SPSS 17 program.

The result of research showed that the knowledge of police officers at Pancur Batu sector on the second week in July was mayority with good and fair and none with low category.

The autopsy action is so important to do in order to reveal criminal action. Hence, the socialization to the community should be conducted by the police of Indonesia either to religion figures, tradition figures, organization and others.
\end{abstract}

Index Terms- Knowledge, autopsy, Police of Pancur Batu sector

\section{INTRODUCTION}

$\mathrm{H}$ igh cases of criminal action is closely related to the community disease nowadays, such as narcotics, alcohol, gambling, promiscuity, and also bad economy condition. Those doers of criminal consider that life is less meaning for them and they act cruelly without humanity sense. Also, they have strong determination to do criminal action.

Five countries with high criminal actions in the world are such as Honduras, South Africa, North Korea, Afganistan and Guatemala. The biggest cases include kidnapping, rapery, murder among gangs and terrorism (Tribun Travel.com). It is the same with Indonesia. The criminal action increases for $38.45 \%$ (Lampost.com). Also, in North Sumatera, the criminal cases in 2019 was still high with the total for 31.388 cases and the highest was narcotics case (Tribun news, 2020).

Considering the area scope of Pancur Baru sector is so wide and located at traffic cross among countries, it causes high incidence of acidents. However, without conducting the autopsy, the cause of the dead is still uncertain to weather the victim is dead as the effect of accident or has been dead first and throw out into the road denoting the victim died as if it is the effect of accident, but with the real cause is murder. Also, many drivers drink alcohol and use narcotics. The disease may cause suddent dead at the time of driving. The report from Jasa Raharja shows that the rate of accident in North Sumatera increases with the victims for 8,558 in 2019 (Antara news, 2020). Also, many cases of die unnaturally such as dead hanging. The cause of the dead cannot be known since the autopsy is not performed with many reasons from the families of the victim.

On the criminal cases and accidents causing the dead of the victims, the cause of the dead is as the first priority for autopsy checking of forensic doctor. It is with the intention to know real cause of one criminal case. To know the cause of the dead of victim, the autopsy to the dead victim is as the only way and also as absolute procedure which must be conducted to assure the dead of the victim. Due to the case, Security Defendance Department of Indonesia Police issued the instruction No. Pol: Ins/E/20/IX/75 regarding ways of request/revocation Visum Et Repertum point 3 stating that: "in case that someone is injured and later dead, the next request letter should be made to ask Visum et Repertum on the body based on only outside checking." The instruction from Head of Police Republic of Indonesia really supports the achievement of target of autopsy checking to the dead victim by performing autopsy action. However, in fact we face in field at mortuary Adam Malik hospital/Forensic Department and Medikolegal FK-USU that there are many requests of Visum et Repertum to dead victim for only outside checking without autopsy. It may be caused by lack knowledge of the police regarding the autopsy and the use of autopsy leading to only outside checking. Also, it may be caused by the refusal from the society either from the families of victim, community figures, religion figures, local government officers and certain community.

The research about the knowledge of police officers regarding the autopsy at Pancur Batu district has not been ever conducted. Based on the background above, the writer is 
interested in knowing the knowledge of police officers about autopsy at Pancur Batu sector.

\section{METHOD}

This research is survey with cross sectional design in form of descriptive to know the description of knowledge of the police officers about autopsy in Pancur Batu sector. The research is carried out at police station Pancur Batu sector. The time of research is conducted since April 2020 up to July 2020 ranging from proposing the title, library research, proposal reading, data collection, data processing, writing and research result description.

The population were all police officers member at Pancur Batu sector. The samples were the police officers at Pancur Batu sector who sign approval sheet as the sample and fill in the questionnaire sheet using total sampling.
All results of questionnaire are collected and assessed in accordance with the theories regarding knowledge level, namely:

1) Good : if the total score obtained 11-15.

2) Fair : if the total score obtained 6-10

3) Low : if the total score obtained 0-5.

4) The instrument tool in this research is questionnaire with 15 questions for the knowledge about autopsy.

5) The way to measure the questionnaire is by giving score 1 for correct answer and 0 for wrong answer. The result of measuring for this research is the total score from the questions given. The obtained data is analyzed using SPSS.

\section{RESULTS}

The research is conducted to 25 respondents at Police Pancur Batu sector in 2020 regarding the knowledge of the police officers Pancur Batu sector about autopsy. The sample characteristics in this research include age, education, rank and working unit.

Table 1

Distribution of Age, Education, Rank and Working Unit

\begin{tabular}{l|l|l|l} 
No & Characteristics of Respondent & Frequency & Percentage \\
\hline 1 & Age (Year) & & \\
& $19-40$ years old & 14 & 56,0 \\
& 41-60 years old & 11 & 44,0 \\
\hline 2 & Education & 21 & \\
\hline & Senior High School & 4 & 84,0 \\
& Scholar & & 16,0 \\
\hline 3 & Position & 7 & \\
\hline & Brigadier & 1 & 28,0 \\
& Bripda & 2 & 4,0 \\
& Briptu & 5 & 8,0 \\
& Bripka & 2 & 20,0 \\
& Aipda & 5 & 8,0 \\
& Aiptu & 1 & 20,0 \\
& Ipda & 2 & 4,0 \\
& Iptu & & 8,0 \\
\hline 4 & Working Unit & 13 & \\
\hline & Traffic Unit & 12 & 52,0 \\
& Crime Unit & 25 & 48,0 \\
\hline & Total & & 100,0
\end{tabular}

Source: Research result 2020 (data analyzed)

\section{Knowledge level about autopsy} follows:

The knowledge level about autopsy in this research is measured with 15 questions and the distribution of the answer is as

Table 2

Knowledge Level of Respondent about Autopsy

\begin{tabular}{|llllllll}
\hline & & \multicolumn{3}{c}{ Answer } & \multicolumn{2}{c}{ Total } \\
\hline No & Question & Right & \multicolumn{2}{c}{ Wrong } & & \\
\hline 1 & $\mathrm{~N}$ & $\%$ & $\mathrm{n}$ & $\%$ & $\mathrm{n}$ & $\%$ \\
\hline & $\begin{array}{l}\text { Visum et Repertum (VeR) is one } \\
\text { of legal proofs in the process of } \\
\text { proving criminal action. }\end{array}$ & 25 & 100.0 & - & - & 25 & 100.0 \\
\hline
\end{tabular}




\begin{tabular}{|c|c|c|c|c|c|c|c|}
\hline 2 & $\begin{array}{l}\text { Autopsy can be carried out by } \\
\text { specialist doctor of forensic } \\
\text { without any demand from } \\
\text { investigator. }\end{array}$ & 4 & 16,0 & 21 & 84,0 & 25 & 100.0 \\
\hline 3 & $\begin{array}{l}\text { VeR consists of VeR of life } \\
\text { victim, VeR of dead victim and } \\
\text { VeR at mental disorder victim }\end{array}$ & 23 & 92,0 & 2 & 8,0 & 25 & 100.0 \\
\hline 4 & $\begin{array}{l}\text { The families of victim may } \\
\text { directly ask for autopsy to the } \\
\text { specialist doctor of forensic. }\end{array}$ & 14 & 56,0 & 11 & 44,0 & 25 & 100,0 \\
\hline 5 & $\begin{array}{l}\text { If any dead victim suspected } \\
\text { for criminal action and traffic } \\
\text { victim, autopsy must be done to } \\
\text { determine the cause of dead. }\end{array}$ & 25 & 100,0 & - & - & 25 & 100,0 \\
\hline 6 & $\begin{array}{l}\text { The base of investigator to ask } \\
\text { VeR to the specialist doctor } \\
\text { of justice, doctor and others } \\
\text { expert is attached in Criminal } \\
\text { Procedure Code } 133 \text {. }\end{array}$ & 25 & 100,0 & - & - & 25 & 100,0 \\
\hline 7 & $\begin{array}{l}\text { According to article } 134 \text { of } \\
\text { Criminal Procedure Code, the } \\
\text { investigator who asks for the } \\
\text { autopsy is obliged to inform } \\
\text { the families of victim. In case } \\
\text { that the families of victim are in } \\
\text { objection, the investigator must } \\
\text { describe in detail regarding the } \\
\text { aim and use of the autopsy. If in } \\
\text { the duration of } 2 \times 24 \text { hours, } \\
\text { there is no interruption from } \\
\text { families, then the autopsy can be } \\
\text { implemented. }\end{array}$ & 22 & 88,0 & 3 & 12,0 & 25 & 100,0 \\
\hline 8 & $\begin{array}{l}\text { The needs of forensic autopsy } \\
\text { do not require the permission } \\
\text { from families of victim. }\end{array}$ & 25 & 100,0 & - & - & 25 & 100,0 \\
\hline 9 & $\begin{array}{l}\text { Those who hinder the } \\
\text { implementation of autopsy can } \\
\text { be sanctioned the criminal action } \\
\text { based on article } 222 \text { Criminal } \\
\text { Procedure Code. }\end{array}$ & 24 & 96,0 & 1 & 4,0 & 25 & 100,0 \\
\hline 10 & $\begin{array}{l}\text { Those who have the right to get } \\
\text { VeR to the doctor in accordance } \\
\text { with article } 6 \text { Criminal } \\
\text { Procedure Code after the } \\
\text { investigator are those with } \\
\text { lowest position as Aiptu. }\end{array}$ & 23 & 92,0 & 2 & 8,0 & 25 & 100,0 \\
\hline 11 & $\begin{array}{l}\text { VeR may be requested to } \\
\text { specialist doctor of justice or } \\
\text { forensic at Medikological. }\end{array}$ & 6 & 24,0 & 19 & 76,0 & 25 & 100,0 \\
\hline 12 & $\begin{array}{l}\text { If in the duration of } 2 \text { days or } 2 \times \\
24 \text { hours, there is no objection or } \\
\text { response from the families of } \\
\text { victim to the dead victim in } \\
\text { accordance with article } 134 \\
\text { verse } 3 \text {, Criminal Procedure } \\
\text { Code, the investigator has the } \\
\text { right to cancel the autopsy. }\end{array}$ & 12 & 48,0 & 13 & 52,0 & 25 & 100,0 \\
\hline
\end{tabular}




\begin{tabular}{|llllllll}
\hline 13 & $\begin{array}{l}\text { The autopsy cost is fully } \\
\text { charged by state based on article } \\
\text { 136 Criminal Procedure Code. }\end{array}$ & 22 & 88,0 & 3 & 12,0 & 25 & 100,0 \\
\hline 14 & $\begin{array}{l}\text { The aim of the autopsy is to } \\
\text { determine the real cause of dead. }\end{array}$ & 25 & 100,0 & - & - & 25 & 100,0 \\
\hline 15 & $\begin{array}{l}\text { The request for Visum et } \\
\text { Repertum (SPV) checking can } \\
\text { be countdown via phone or SMS } \\
\text { or WA. }\end{array}$ & 6 & 24,0 & 19 & 76,0 & 25 & 100,0 \\
\end{tabular}

Source: Research result 2020 (data analyzed)

Table 3

Knowledge Level Category of Respondent about Autopsy

\begin{tabular}{|l|l|l|l|}
\hline No & Knowledge Category & Total $(\mathbf{n})$ & Frequency $(\%)$ \\
\hline 1 & Good & $\mathbf{1 7}$ & $\mathbf{6 8 , 0}$ \\
\hline $\mathbf{2}$ & Fair & $\mathbf{8}$ & $\mathbf{3 2 , 0}$ \\
\hline $\mathbf{3}$ & Low & - & - \\
\hline & Total & $\mathbf{2 5}$ & $\mathbf{1 0 0 , 0}$ \\
\hline
\end{tabular}

Source: Research result 2020 (data analyzed)

Table 4

Knowledge Level about autopsy based on age

\begin{tabular}{|c|c|c|c|c|c|c|c|c|}
\hline \multicolumn{9}{|l|}{ Knowledge } \\
\hline Age & \multicolumn{2}{|c|}{ Good } & \multicolumn{2}{|c|}{ Fair } & \multicolumn{2}{|c|}{ Low } & \multicolumn{2}{|c|}{ Total } \\
\hline $19-40$ years old & 11 & 78,6 & 3 & 21,4 & $\mathbf{0}$ & $\mathbf{0}$ & 14 & 100,0 \\
\hline 41-60 years old & 6 & 54,5 & 5 & 45,5 & 0 & 0 & 11 & 100,0 \\
\hline Total & 17 & 68.0 & 8 & 32,0 & $\mathbf{0}$ & $\mathbf{0}$ & 25 & 100,0 \\
\hline
\end{tabular}

Source: Research result 2020 (data analyzed)

Table 5

Knowledge Level about autopsy based on education

\begin{tabular}{|c|c|c|c|c|c|c|c|c|}
\hline \multicolumn{9}{|l|}{ Knowledge } \\
\hline Education & \multicolumn{2}{|c|}{ Good } & \multicolumn{2}{|c|}{ Fair } & \multicolumn{2}{|c|}{ Low } & \multicolumn{2}{|c|}{ Total } \\
\hline Senior High School & 14 & 66,7 & 7 & 33,3 & $\mathbf{0}$ & $\mathbf{0}$ & 21 & 100,0 \\
\hline Scholar & 3 & $\mathbf{7 5 , 0}$ & $\mathbf{1}$ & 25,0 & $\mathbf{0}$ & $\mathbf{0}$ & 4 & 100,0 \\
\hline Total & 17 & 68.0 & 8 & 32,0 & $\mathbf{0}$ & $\mathbf{0}$ & 25 & 100,0 \\
\hline
\end{tabular}

Source: Research result 2020 (data analyzed)

Table 6

Knowledge Level about autopsy based on rank

\begin{tabular}{|l|l|l|l|l|l|l|l|l|}
\hline Knowledge & \multicolumn{9}{l|}{ Good } & \multicolumn{1}{l|}{ Fair } & \multicolumn{1}{l|}{ Low } & \multicolumn{2}{l|}{ Total } \\
\hline Rank & $\mathbf{6}$ & $\mathbf{8 5 , 7}$ & $\mathbf{1}$ & $\mathbf{1 4 , 3}$ & $\mathbf{0}$ & $\mathbf{0}$ & $\mathbf{7}$ & $\mathbf{1 0 0 , 0}$ \\
\hline Brigadier & $\mathbf{1}$ & $\mathbf{1 0 0 , 0}$ & $\mathbf{0}$ & $\mathbf{0}$ & $\mathbf{0}$ & $\mathbf{0}$ & $\mathbf{1}$ & $\mathbf{1 0 0 , 0}$ \\
\hline Bripda & $\mathbf{1}$ & $\mathbf{5 0 , 0}$ & $\mathbf{1}$ & $\mathbf{5 0 , 0}$ & $\mathbf{0}$ & $\mathbf{0}$ & $\mathbf{2}$ & $\mathbf{1 0 0 , 0}$ \\
\hline Briptu & $\mathbf{3}$ & $\mathbf{6 0 , 0}$ & $\mathbf{2}$ & $\mathbf{4 0 , 0}$ & $\mathbf{0}$ & $\mathbf{0}$ & $\mathbf{5}$ & $\mathbf{1 0 0 , 0}$ \\
\hline Bripka & $\mathbf{1}$ & $\mathbf{5 0 , 0}$ & $\mathbf{1}$ & $\mathbf{5 0 , 0}$ & $\mathbf{0}$ & $\mathbf{0}$ & $\mathbf{2}$ & $\mathbf{1 0 0 , 0}$ \\
\hline Aipda & $\mathbf{2}$ & $\mathbf{4 0 , 0}$ & $\mathbf{3}$ & $\mathbf{6 0 , 0}$ & $\mathbf{0}$ & $\mathbf{0}$ & $\mathbf{5}$ & $\mathbf{1 0 0 , 0}$ \\
\hline Aiptu & $\mathbf{1}$ & $\mathbf{1 0 0 , 0}$ & $\mathbf{0}$ & $\mathbf{0}$ & $\mathbf{0}$ & $\mathbf{0}$ & $\mathbf{1}$ & $\mathbf{1 0 0 , 0}$ \\
\hline Ipda & $\mathbf{2}$ & $\mathbf{1 0 0 , 0}$ & $\mathbf{0}$ & $\mathbf{0}$ & $\mathbf{0}$ & $\mathbf{0}$ & $\mathbf{2}$ & $\mathbf{1 0 0 , 0}$ \\
\hline Iptu & $\mathbf{1 7}$ & $\mathbf{6 8 , 0}$ & $\mathbf{8}$ & $\mathbf{3 2 , 0}$ & $\mathbf{0}$ & $\mathbf{0}$ & $\mathbf{2 5}$ & $\mathbf{1 0 0 , 0}$ \\
\hline Total & & & & & & & \\
\hline
\end{tabular}

Source: Research result 2020 (data analyzed) 
Table 7

Knowledge Level about autopsy based on working unit

\begin{tabular}{|c|c|c|c|c|c|c|c|c|}
\hline \multicolumn{9}{|l|}{ Knowledge } \\
\hline Working Unit & \multicolumn{2}{|c|}{ Good } & \multicolumn{2}{|c|}{ Fair } & \multicolumn{2}{|c|}{ Low } & \multicolumn{2}{|c|}{ Total } \\
\hline Traffic Unit & 10 & 76,9 & 3 & 23,1 & $\mathbf{0}$ & $\mathbf{0}$ & 13 & 100,0 \\
\hline Crime Unit & 7 & 58,3 & 5 & 41,7 & $\mathbf{0}$ & $\mathbf{0}$ & 12 & 100,0 \\
\hline Total & 17 & 68.0 & 8 & 32,0 & $\mathbf{0}$ & $\mathbf{0}$ & 25 & 100,0 \\
\hline
\end{tabular}

Source: Research result 2020 (data analyzed) 


\section{CONCLUSION AND SUGGESTION}

\section{Conclusion}

Based on the findings of research and data analysis about the knowledge level of police officers at Pancur Batu sector, the conclusions can be taken as follows:

1. Mayority of respondents have good knowledge about autopsy for 17 respondents $(68,0 \%)$.

2. Seen from the age, the age category with good knowledge is between 19- 40 years old for 11 respondents $(78,6 \%)$.

3. Seen from education level, mayority of respondents with good knowledge are the respondents with Scholar Education level for 3 respondents $(75,0 \%)$.

4. Seen from rank, mayority of respondents with good knowledge are the respondents with Iptu rank for 2 respondents $\quad(100,0 \%)$.

5. Seen from working unit, mayority of respondents with good knowledge are the respondents from Traffic Unit for 10 respondents $(76,9 \%)$.

\section{Suggestions}

1. To the Head of Police Pancur Batu sector, it is suggested to pay attention for the aspects of autopsy in order to make the knowledge of police officers regarding autopsy can be more maximized and should give socialization to the community about the aim of autopsy.

2. To the police officers at Pancur Batu sector, it is suggested to add more knowledge about autopsy in order the implementation of autopsy can be more effective.

3. To other researchers, it is recommended to carry out similar research with wider scale in order to get new research and more accurate.

\section{REFERENCES}

[1] Abdussalam, 2006. Forensik. Jakarta: Restu Agung.

[2] Afandi, D, 2008. Visum Et Repertum pada Orang Mati. Skripsi, Universitas Sumatera Utara.

[3] Afif, F, 2010. Fungsi Visum Et Repertum dalam Proses Penyidikan Kasus Tindakan Pidana Penganiayaan. Skripsi, Universitas Andalas, Sumatera Barat.
[4] Aksara, Mubarak, W.I., Chayatin, N., Rozikin, K., Supradi. 2013. Promosi Kesehatan Sebuah Pengantar Proses Belajar Mengajar dalam Pendidikan. Yogyakarta: Graha Ilmu

[5] Amir, A, 1995. Rangkaian Ilmu Kedokteran Forensic. Medan: Ramadhan.

[6] Arikunto, S, 2007. Analisa Data Penelitian Deskriptif. Dalam: Arikunto, S., ed. Manajemen Penelitian. Jakarta: Rineka Cipta, 262-296.

[7] Dahlan, S, \& Trisnadi, S, 2019. Ilmu Kedokteran Forensik, Unissula, Fakultas Kedokteran, Semarang.

[8] Hamzah, A, 1996. Hukum Acara Pidana Indonesia. Jakarta: Sinar Grafika.

[9] Idries, AM, 2009. Pedoman Praktis Ilmu Kedokteran Forensik Bagi Praktisi Hukum, Jakarta: Sagung Seto.

[10] Idris, AM, 1997. Pedoman Ilmu Kedokteran Forensik Edisi Pertama. Jakarta: Binarupa.

[11] Notoadmodjo, S, 2003. Ilmu Kesehatan Masyarakat. Jakarta: Rineka Cipta.

[12] Notoadmodjo, S, 2005. Promosi Kesehatan dan Ilmu Prilaku. Jakarta: Rineka Cipta.

[13] Notoadmodjo, S, 2010. Metodologi Penelitian Kesehatan. Jakarta: Rineka Cipta.

[14] Pratiwi, T, 2010. Penerapan Sanksi Pidana yang Dilakukan Secara Berlanjut di Pengadilan Negeri Karanganya. Skripsi, Universitas Sebelas Maret.

[15] Sastroasmoro, S. \& Ismael, Sofyan, 1995. Dasar-dasar Metodologi Penelitian Klinis.

[16] Soularto, Dirwan Suryo dan Eka Siwi Dwi Cahyanti, 2009. Analisis Kualitas.

[17] http://medan.tribunnews.com/2020/01/02angka-kriminalitas-di-sumut2019-tergolong-tinggi-total-31388-kasus-tertinggi-kejahatan-narkoba (diakses tanggal 2 Juni 2020)

[18] https://sumut.antaranews.com/berita/285298/jasa-raharja-jumlahkecelakaanlalu-lintas-di-sumut-meningkat (diakses tanggal 2 Juni 2020)

[19] https://travel.tribunnews.com (diakses tanggal 2 Juni 2020)

[20] https://www.lampost.com (diakses tanggal 2 Juni 2020)

\section{AUTHORS}

First Author - Erwin Sembiring, Department of Forensic and Medicolegal of Faculty of Medicin Universitas Sumatera Utara, Gmail : sembiringerwin366@gmail.com

Second Author - Surjit Singh, Department of Forensic and Medicolegal of Faculty of Medicin Universitas Sumatera Utara Third Author - Agustinus Sitepu, Department of Forensic and Medicolegal of Faculty of Medicin Universitas Sumatera Utara 